\title{
KEMAMPUAN SISWA SMP KOTA KUPANG DALAM MENYELESAIKAN MASALAH HOTS MATEMATIKA
}

\author{
Uke Ralmugiz \\ Program Studi Pendidikan Matematika, Universitas Muhammadiyah Kupang \\ ukeralmugiz@unmuhkupang.ac.id
}

\begin{abstract}
Abstrak
Penelitian ini bertujuan untuk mendeskripsikan kemampuan siswa SMP Kota Kupang dalam menyelesaikan masalah HOTS. Penelitian ini adalah penelitian kuantitatif dengan jenis survei. Populasi dalam penelitian ini adalah siswa kelas VII SMP se-Kota Kupang. Pengambilan sampel dilakukan dengan menggunakan teknik purposive sampling. Teknik pengumpulan data dalam penelitian ini adalah teknik tes dengan instrumen tes soal HOTS matematika. Teknik analisis data yang digunakan adalah teknik analisis data deskriptif dengan menggunakan bantuan Quest. Secara keseluruhan rata-rata kemampuan siswa SMP Kota Kupang dalam menyelesaikan masalah HOTS berada pada kategori sedang (62\%), 28\% siswa memiliki kemampuan yang tinggi dalam menyelesaikan masalah HOTS, dan 9\% siswa memiliki kemampuan rendah dalam menyelesaikan masalah HOTS.
\end{abstract}

Kata Kunci: Penyelesaian Masalah, HOTS.

\begin{abstract}
This study aims to describe the ability of Kupang City Middle School students to solve HOTS problems. This research was a quantitative research with survey type. The population in this study were seventh grade students of SMP throughout Kupang City. Futhemore sampling was carried out using purposive sampling. The data collection technique in this study was a test technique with HOTS mathematical test instruments. The data analysis technique used is descriptive data analysis technique using the help of Quest. Overall, the average ability of Kupang City Middle School students in solving HOTS problems is in the moderate category (62\%), $28 \%$ of students have high ability to solve HOTS problems, and $9 \%$ of students have low ability to solve HOTS problems.
\end{abstract}

Keywords: Problem Solving, HOTS.

\section{PENDAHULUAN}

Salah satu cita-cita luhur Bangsa Indonesia yang tertuang dalam pembukaan Undang-Undang Dasar 1945 adalah mencerdaskan kehidupan bangsa. Upaya untuk mewujudkan cita-cita tersebut adalah melalui pendidikan. Salah satu pelajaran penting dalam pendidikan indonesia adalah matematika, dimana matematika adalah pelajaran wajib dari tingkat dasar sampai tingkat menengah, hal ini sesuai dengan Undang-Undang Republik Indonesia Nomor 20 Tahun 2013 tentang sistem Pendidikan Nasional. Dalam silabus mata pelajaran matematika SMP/MTs [1], salah satu tujuan mata pelajaran matematika untuk jenjang dasar dan menengah adalah menumbuhkan sikap positif seperti sikap logis, kritis, cermat, teliti, dan tidak mudah menyerah dalam memecahkan masalah. Upaya mewujudkan tujuan tersebut adalah siswa dibekali berbagai keterampilan, salah satunya adalah keterampilan berpikir tingkat tinggi atau Higher Order Thinking Skills (HOTS). 
Berpikir dapat dibagi menjadi empat kategori yaitu creative, critical, basic, dan recall, namun yang masuk dalam ranah tingkat tinggi hanya creative dan critical [2]. Pendapat lain dikemukakan ole Haladyna [3], yang menyatakan bahwa HOTS mencakup memahami fakta, konsep, prinsip, dan prosedur. Selanjutnya Edwards dan Briers [4] menyatakan bahwa istilah yang berbeda telah digunakan untuk mendeskripsikan proses berpikir, mengingat dan tingkat dalam pemrosesan termasuk dalam keterampilan berpikir tingkat rendah, sedangkan mencipta dan mengevaluasi termasuk dalam kategori HOTS. Sedangkan pada taksonomi Bloom, pengetahuan, pemahaman dan aplikasi termasuk dalam kategori LOTS (Lower Order Thinking Skill), tiga tingkat lainnya yaitu menganalisis, menyintesis, dan mengevaluasi lainnya termasuk dalam HOTS [5].

Orientasi pendidikan sekarang tidak sebatas transfer ilmu dari guru ke siswa, namun lebih kepada menyiapkan siswa untuk menghadapi era yang semakin maju. Pada praktiknya HOTS sangat diperlukan peserta didik, hal ini dikarenakan bahwa permasalahan dalam kehidupan yang sesungguhnya (real life problems) ialah bersifat kompleks, tidak terstruktur, rumit, baru, dan memerlukan keterampilan berpikir yang lebih dari sekedar mengaplikasikan apa yang telah dipelajari [6]. Newmann, King, dan Carmichael [7] menyatakan bahwa HOTS membuat siswa memahami konsep lebih baik, dengan HOTS siswa dapat membedakan ide secara jelas, memberikan argumen dengan baik, mampu memecahkan masalah, mampu mengkonstruksi penjelasan, mampu berhipotesis, dan memahami hal kompleks menjadi lebih jelas. Pengembangan keterampilan berpikir tingkat tinggi bagi siswa akan menghasilkan antara lain: tingkat kemahiran siswa dalam strategi pemecahan masalah matematika membaik, tingkat kepercayaan diri siswa dalam matematika meningkat, dan prestasi belajar siswa dalam masalah non-rutin yang menuntut keterampilan berpikir tingkat tinggi meningkat [8].

Kenyataannya HOTS siswa Indonesia masih tergolong rendah, hal tersebut dapat dilihat dari peringkat Indonesia dalam Trends in International Mathematics and Science Study (TIMSS). Peringkat indonesia dalam TIMS disajikan pada Tabel 1. Rendahnya hasil TIMSS tersebut tentunya dapat disebabkan oleh bermacam-macam faktor, namun salah satunya karena rendahnya HOTS siswa Indonesia, sesuai pendapat Winataputra [6] tentang penelitian TIMSS yang menunjukkan masih rendahnya prestasi siswa Indonesia dalam matematika, terutama terkait soal-soal Higher Order Thinking Skills (HOTS).

Tabel 1. Peringkat Indonesia dalam TIMMS

\begin{tabular}{ccccc}
\hline $\begin{array}{c}\text { Tahun } \\
\text { Studi }\end{array}$ & $\begin{array}{c}\text { Rata-rata } \\
\text { Indonesia }\end{array}$ & $\begin{array}{c}\text { Rata-rata } \\
\text { Internasional }\end{array}$ & $\begin{array}{c}\text { Peringkat } \\
\text { Indonesia }\end{array}$ & $\begin{array}{c}\text { Negara } \\
\text { Peserta }\end{array}$ \\
\hline 1999 & 403 & 487 & 32 & 38 \\
2003 & 397 & 500 & 34 & 48 \\
2007 & 411 & 467 & 36 & 48 \\
2011 & 386 & 500 & 38 & 42 \\
2015 & 397 & 500 & 44 & 49 \\
\hline
\end{tabular}

Berdasarkan data hasil Ujian Nasional matematika Tingkat SMP Negeri di Kota Kupang tahun 2017 yang dihimpun melalui halaman website resmi Puspendik [9], diketahui bahwa rata-rata Nilai UN matematika SMP di Kota 
Kupang adalah 35,32, nilai tersebut tergolong rendah dan mengindikasikan bahwa HOTS siswa SMP Kota Kupang Rendah juga dikarenakan UN matematika tahun 2017 berbasis HOTS. Untuk itu perlu dilakukan suatu penelitian untuk menganalisis kemampuan menyelesaikan masalah HOTS siswa SMP Kota kupang agar dapat ditemukan sebuah solusi dalam meningkatkan HOTS siswa SMP Kota Kupang. Karena HOTS merupakan modal utama dalam menyiapkan diri peserta didik dalam menghadapi era yang semakin maju.

\section{METODE}

\section{Jenis Penelitian}

Penelitian ini adalah penelitian kuantitatif dengan jenis penelitian survey. Menurut Sugiyono [10] penelitian survey adalah penelitian yang dilakukan pada populasi besar maupun kecil, akan tetapi data yang dianalisis adalah data dari sampel yang diambil dari populasi tersebut, sehingga ditemukan kejadian-kejadian relative, distribusi, dan hubungan-hubungan antar variabel.

\section{Subjek Penelitian}

Subjek penelitian ini adalah siswa kelas VIII SMP. Pengambilan sampel dilakukan dengan menggunakan teknik purposive sampling dengan memperhatikan tingkatan rata-rata nilau UN matematika dan akreditasi sekolah dalam populasi yaitu SMP di Kota Kupang. Sekolah yang telah dipilih kemudian masing-masing satu kelas unggulan di sekolah tersebut yang dijadikan sampel penelitian, hasilnya adalah 31 siswa di SMP UN Terendah dengan akreditasi sekolah C, 32 siswa di SMP UN Sedang dengan akreditasi sekolah B, dan 32 siswa di SMP UN Tertinggi dengan akreditasi sekolah A.

\section{Teknik dan Instrumen Pengumpulan Data}

Teknik pengumpulan data penelitian ini adalah tes, tes digunakan untuk mengumpulkan data atau informasi tentang jawaban dan langkah pengerjaan yang dilakukan siswa dalam menyelesaikan soal matematika yakni soal HOTS dengan langkah penyelesaian Polya. Instrumen yang digunakan adalah instrumen tes masalah HOTS, untuk materinya adalah materi matematika kelas VII.

\section{Teknik Analisis Data}

Teknik yang digunakan dalam analisis data yaitu analisis deskriptif, menganalisis setiap jawaban untuk setiap soal berdasarkan langkah penyelesaian Polya, kemudian menentukan persentase siswa yang menjawab benar untuk setiap langkah penyelesaian berdasarkan langkah Polya untuk setiap soalnya. Setelahnya mendapatkan tingkat kemampuan siswa dalam menyelesaikan HOTS dengan menggunakan bantuan Quest.

\section{HASIL DAN PEMBAHASAN}

Untuk mengetahui kemampuan siswa dalam menyelesaikan masalah HOTS, diberikan soal HOTS sebanyak tiga yang kemudian diselesaikan siswa berdasarkan langkah penyelesaian Polya. Penyelesaian masalah menurut Polya terdiri dri empat tahapan, yaitu: memahami masalah, membuat rencana penyelesaian, melaksanakan rencana, dan melihat kembali. Semua soal yang 
didistribusikan ke siswa, setelah selesai dikerjakan setelahnya adalah melakukan perekapan data hasil pekerjaan siswa dengan cara dikoding dan dianalisis menggunakan Quest, hasilnya menggambarkan kemampuan siswa SMP Kota Kupang dalam menyelesaikan HOTS. Hasil penyelesaian masalah HOTS untuk setiap soal berdasarkan langkah penyelesaian masalah menurut Polya ditunjukkan pada Tabel 2.

Tabel 2. Persentase Jawaban Benar Berdasarkan Langkah Polya

\begin{tabular}{|c|c|c|c|c|}
\hline Sekolah & Langkah Polya & Soal 1 & Soal 2 & Soal 3 \\
\hline \multirow{8}{*}{ SMP Nilai UN Terendah } & \multirow{2}{*}{ Langkah 1} & 31 & 31 & 22 \\
\hline & & $100 \%$ & $100 \%$ & $71 \%$ \\
\hline & \multirow{2}{*}{ Langkah 2} & 27 & 13 & 9 \\
\hline & & $87 \%$ & $42 \%$ & $29 \%$ \\
\hline & \multirow{2}{*}{ Langkah 3} & 19 & 6 & 3 \\
\hline & & $61 \%$ & $19 \%$ & $10 \%$ \\
\hline & \multirow{2}{*}{ Langkah 4} & 0 & 0 & 0 \\
\hline & & $0 \%$ & $0 \%$ & $0 \%$ \\
\hline \multirow{6}{*}{ SMP Nilai UN Sedang } & \multirow[b]{2}{*}{ Langkah 1} & 32 & 32 & 32 \\
\hline & & $100 \%$ & $100 \%$ & $100 \%$ \\
\hline & \multirow{2}{*}{ Langkah 2} & 31 & 31 & 30 \\
\hline & & $97 \%$ & $97 \%$ & $94 \%$ \\
\hline & \multirow{2}{*}{ Langkah 3} & 23 & 26 & 25 \\
\hline & & $72 \%$ & $81 \%$ & $78 \%$ \\
\hline \multirow{10}{*}{ SMP Nilai UN Tertinggi } & \multirow{2}{*}{ Langkah 4} & 13 & 5 & 5 \\
\hline & & $41 \%$ & $16 \%$ & $16 \%$ \\
\hline & \multirow{2}{*}{ Langkah 1} & 32 & 32 & 32 \\
\hline & & $100 \%$ & $100 \%$ & $100 \%$ \\
\hline & \multirow{2}{*}{ Langkah 2} & 29 & 29 & 30 \\
\hline & & $91 \%$ & $91 \%$ & $94 \%$ \\
\hline & \multirow{2}{*}{ Langkah 3} & 23 & 26 & 28 \\
\hline & & $72 \%$ & $81 \%$ & $88 \%$ \\
\hline & \multirow{2}{*}{ Langkah 4} & 15 & 15 & 14 \\
\hline & & $47 \%$ & $47 \%$ & $44 \%$ \\
\hline \multirow{8}{*}{ Total } & \multirow{2}{*}{ Langkah 1} & 95 & 95 & 86 \\
\hline & & $100 \%$ & $100 \%$ & $91 \%$ \\
\hline & \multirow{2}{*}{ Langkah 2} & 87 & 73 & 69 \\
\hline & & $92 \%$ & $77 \%$ & $73 \%$ \\
\hline & \multirow{2}{*}{ Langkah 3} & 65 & 58 & 56 \\
\hline & & $68 \%$ & $61 \%$ & $59 \%$ \\
\hline & \multirow[t]{2}{*}{ Langkah 4} & 28 & 20 & 19 \\
\hline & & $29 \%$ & $21 \%$ & $20 \%$ \\
\hline
\end{tabular}

Berdasarkan Tabel 2, diketahui bahwa Siswa di Setiap Sekolah hampir semuanya dapat melakukan tahap pertama penyelesaian masalah menurut Polya dengan benar, artinya siswa dapat mengidentifikasi apa saja yang diketahui dan apa yang ditanya dalam soal. Pada Langkah kedua sebagian besar dapat selesaikan dengan benar yaitu dengan rata-rata $80 \%$ siswa menyelesaikan dengan baik. Pada langkah ketiga semakin berkurang siswa yang dapat menyelesaikan dengan benar 
sekitar 63\%. Pada langkah terakhir yaitu langkah melihat kembali, semakin sedikit siswa yang dapat menyelesaikan dengan benar yaitu sekitar 23\%. Tahap penyelesaian masalah yang ditawarkan oleh Polya saling berkaitan satu dengan yang lain, pada langkah terakhir sebenarnya memberikan kesempatan kepada siswa untuk mengecek kembali jawaban mereka, namun dari data yang diperoleh kebanyakan siswa tidak memaksimalkan langkah itu dengan baik.

Berdasarkan data yang diperoleh, dapat juga diklasifikasi kemampuan menyelesaikan masalah HOTS, dengan aplikasi Quest diperoleh hasil sebagaimana ditunjukkan pada Tabel 3.

Tabel 3. kemampuan menyelesaikan masalah HOTS

\begin{tabular}{ccccc}
\hline \multirow{2}{*}{ Sekolah } & \multicolumn{4}{c}{ Kemampuan } \\
& Tinggi & Sedang & Rendah & Total \\
\hline \multirow{2}{*}{ SMP Nilai UN Terendah } & 1 & 24 & 6 & $\mathbf{3 1}$ \\
& $3 \%$ & $77 \%$ & $20 \%$ & $\mathbf{1 0 0 \%}$ \\
SMP Nilai UN Sedang & 10 & 21 & 1 & $\mathbf{3 2}$ \\
\multirow{3}{*}{ SMP Nilai UN Tertinggi } & $31 \%$ & $66 \%$ & $3 \%$ & $\mathbf{1 0 0 \%}$ \\
& 16 & 14 & 2 & $\mathbf{3 2}$ \\
& $50 \%$ & $44 \%$ & $6 \%$ & $\mathbf{1 0 0 \%}$ \\
\hline \multirow{2}{*}{ Total } & $\mathbf{2 7}$ & $\mathbf{5 9}$ & $\mathbf{9}$ & $\mathbf{9 5}$ \\
& $\mathbf{2 8 \%}$ & $\mathbf{6 3 \%}$ & $\mathbf{9 \%}$ & $\mathbf{1 0 0 \%}$ \\
\hline
\end{tabular}

Secara keseluruhan rata-rata kemampuan siswa SMP Kota Kupang dalam menyelesaikan masalah HOTS berada pada kategori sedang. 28\% (27) siswa memiliki kemampuan yang tinggi dalam menyelesaikan masalah HOTS, dan 9\% (9) siswa memiliki kemampuan yang rendah dalam menyelesaikan masalah HOTS. Hasil ini juga selaras dengan hasil UN matematika SMP Kota Kupang, dimana Sekolah dengan pencapaian hasil UN matematika rendah hanya 3\% siswa yang memiliki kemampuan tinggi penyelesaian soal HOTS, dan yang tinggi pencapaian UN matematikanya juga siswa yang masuk kategori tinggi dalam penyelesaian soal HOTS mencapai 50\%.

\section{KESIMPULAN}

Secara keseluruhan rata-rata kemampuan siswa SMP Kota Kupang dalam menyelesaikan masalah HOTS berada pada kategori sedang. $28 \%$ siswa memiliki kemampuan yang tinggi, dan dan 9\% siswa memiliki kemampuan yang rendah dalam menyelesaikan masalah HOTS matematika. Hasil penelitian ini diharapkan menjadi dasar bagi sekolah khususnya SMP Kota Kupang dalam proses pembelajaran matematika untuk meningkatkan HOTS siswa.

\section{DAFTAR RUJUKAN}

[1]. Mendikbud. (2016). Silabus Mata Pelajaran Matematika sekolah Menengah Pertama/Madrasah Tsanawiyah.

[2]. Krulik, S. \& Rudnick, J. A. (1999). The new sourcebook for teaching reasoning and problem solving in elementary school. Needham Heights: Allyn \& Bacon. 
[3]. Haladyna, T. M. (2004). Developing and validating multiple-choice test items (3 ${ }^{\text {rd }}$ ed.). Mahwah, New Jersey: Lawrence Erlbaum Associates.

[4]. Edwards, M. C., \& Briers, G. (2000). Higher-order thinking versus lower-order thinking skills: Does school-day scheduling pattern influence achievement at different levels of learning? Journal of Southern Agricultural Education Research, 50(1), 15-23.

[5]. Saido, G. M., Siraj, A., Nordin, A. B. B., \& Al Amedy, O. S. (2015). Higher order thinking skills among secondary school students in science learning. The Malaysian Online Journal of Education Science, 3(3), 13-20.

[6]. Riadi, A. \& Retnawati, H. (2014). Pengembangan perangkat pembelajaran untuk meningkatkan HOTS pada kompetensi bangun ruang sisi datar. Pythagoras: Jurnal Pendidikan Matematika, 9(2), 126-135.

[7]. Newmann, F. M., King, M. B., \& Carmichael, D. L. (2007). Authentic instruction and assessment: Common standards for rigor and relevance in teaching academic subjects. Des Moines, IA: Department of Education.

[8]. Butkowski, J., Corrigan, C., Nemeth, T., \& Spencer, L. (1994). Improving student higherorder thinking skills in mathematics. Theses. Mathematics Education Research, Saint Xavier University-IRI, Fied-Based Master's Program

[9]. https://puspendik.kemdikbud.go.id/hasil-un/

[10]. Sugiyono. (2014). Metode Penelitian Pendidikan Pendekatan Kuantitatif, Kualitatif, dan $R \& D$. Bandung: Alfabeta. 